\title{
Potential Use of Biotherapeutic Bacteria to Target Colorectal Cancer-Associated Taxa
}

\author{
Garreth W. Lawrence ${ }^{1}$, Máire Begley ${ }^{1,2}$, Paul D. Cotter ${ }^{2,3}$ and Caitriona M. Guinane ${ }^{1, *}$ \\ 1 Department of Biological Sciences, Cork Institute of Technology, Cork T12 P928, Ireland; \\ Garreth.lawrence@mycit.ie (G.W.L.); Maire.begley@cit.ie (M.B.) \\ 2 APC Microbiome Ireland, University College Cork, Cork T12 YN60, Ireland; paul.cotter@teagasc.ie \\ 3 Teagasc Food Research Centre, Moorepark, Fermoy, Cork P61 C996, Ireland \\ * Correspondence: caitriona.guinane@cit.ie
}

Received: 20 December 2019; Accepted: 29 January 2020; Published: 30 January 2020

\begin{abstract}
The role of the gut microbiome in human health and disease is the focus of much attention. It has been widely agreed upon that our gut bacteria play a role in host immunity, nutrient absorption, digestion, metabolism, and other key drivers of health. Furthermore, certain microbial signatures and specific taxa have also been associated with the development of diseases, such as obesity; inflammatory bowel disease; and, indeed, colorectal cancer (CRC), which is the focus of this review. By extension, such taxa represent potential therapeutic targets. In particular, the emerging human pathogen Fusobacterium nucleatum represents an important agent in CRC development and its control within the gastrointestinal tract is desirable. This paper reviews the principal bacterial pathogens that have been associated with CRC to date and discusses the in vitro and human studies that have shown the potential use of biotherapeutic strains as a means of targeting CRC-associated bacteria.
\end{abstract}

Keywords: colorectal cancer; microbiota; Fusobacterium nucleatum; probiotics; biotherapeutics

\section{Introduction}

Colorectal cancer (CRC) refers to cancer of the rectum or colon [1]. CRC accounts for 9.2\% of all cancer diagnoses globally, corresponding to 1.096 million cases, and is the second leading cause of cancer-related deaths worldwide [2]. Colorectal tumorigenesis is attributed to genomic and/or epigenomic instability, resulting in the formation of neoplastic lesions [3,4]. More specifically, such instabilities can promote mutations that result in the inactivation of tumour suppressor genes and the activation of oncogenes, leading to colonic cell malignancies [5]. Risk factors for CRC include excessive alcohol consumption, smoking, and lack of exercise, and epidemiological studies have shown diets rich in red meat and animal fat may also promote CRC development [6] whereas a diet heavy in fruit and vegetables can have a protective effect [7]. Strong evidence has also been put forward for a role of specific human gut microbes in CRC development and progression [8-11].

Despite the advances in cancer therapeutics, including surgery and chemotherapy [12,13], in recent years, CRC remains one of the most aggressive and invasive malignancies [14]. Chemotherapy can damage healthy cells including hair follicle cells, mucous membranes of oral cavities, and the gastrointestinal tract, adversely affecting erythrocytes and leukocytes [15]. Surgical procedures such as colectomies may disrupt the resident gut microbiota, favouring the growth of harmful bacteria [16]. Therefore, nontoxic, noninvasive alternative therapeutics and, indeed, preventative approaches are highly desirable.

In this review, the microbial influence on the development of CRC is examined, with a focus on bacterial pathogens such as the emerging human pathogen Fusobacterium nucleatum that has been recently strongly associated with colon tumorigenesis. Bacterial strains that inhibit the CRC-associated 
pathogen F. nucleatum and that reduce CRC-associated taxa within the gut microbiota and, therefore, have the potential to contribute to CRC prevention by acting as biocontrol agents are also discussed.

\section{The Gut Microbiota of CRC Patients}

The gut microbiome contains over 100 trillion microbes that play crucial roles in host health, and the maintenance of gut homeostasis is largely dependent on the symbiotic interactions between microbes and the digestive tract [17], while an imbalance in the gut microbiome can promote the secretion of bacterial toxins (virulence factors) and carcinogenic metabolites (hydrogen sulfide), decrease beneficial metabolites (butyrate), compromise the intestinal barrier function, cause immune dysregulation, and lead to cellular proliferation which can contribute to CRC [18].

Many studies have assessed the gut microbiome of CRC patients, revealing a number of patterns [19]. While there are variations in the microbial composition across different studies, detection methods, and sample types, several studies have consistently found increased abundances of the genus Fusobacterium in the gut microbiome of CRC patients [20-26]. While high Fusobacterium abundances are consistent, several other genera have also been found to be elevated in both tissue and stool samples of CRC, including Peptostreptococcus [20-22], Streptococcus [20,21,24], Porphyromonas [21,23], and Selenomonas [21,22]. In contrast, the butyrate (a short chain fatty acid (SCFA))-producing genus Roseburia is consistently reduced in CRC patients [20-22], while other butyrate-producing taxa were also underrepresented such as Lachnospiraceae [23] and Ruminococcaceae [25] (Table 1). Some representative studies are summarised here. For instance, Wang et al. [20] investigated the microbial composition of CRC patients in comparison to healthy controls using 16S rRNA amplicon (V3) sequencing of faecal samples. A clear alteration in microbial composition was observed, with an increase in the relative abundance of the genera Fusobacterium, Enterococcus, Escherichia/Shigella, Klebsiella, Streptococcus, and Peptostreptococcus and with a reduction in butyrate-producing bacteria, specifically Roseburia, in CRC patients. In another study, Gao et al. [21] observed similar trends using compositional 16S rDNA sequencing of cancerous tissue and found increased numbers of Fusobacterium, Streptococcus, Peptostreptococcus, Porphyromonas, and Selenomonas. Again, low levels of Roseburia were detected in comparison to healthy controls. Notably, there were significant differences in the relative abundances of Fusobacterium in malignant tissue compared to noncancerous mucosa, with $8.5 \%$ and $4.13 \%$, respectively. Inconsistencies, however, are also evident between certain studies. For instance, Hibberd et al. [22] reported an enrichment of Fusobacterium, Peptostreptococcus, and Selenomonas and a depletion of Roseburia. However, the same study found lower abundances of Streptococcus in the tumour tissue of CRC patients, which was inconsistent with Gao's findings. In another study, low abundances of Lachnospiraceae was significantly associated with CRC [23]. Indeed, Flemer et al. [27] postulated the protective effects of the butyrate-producing family Lachnospiraceae against CRC in an oral, faecal, and colonic mucosal metagenomic analysis. Butyrate, an intestinal microbial metabolite, demonstrates anti-CRC properties through several mechanisms including histone deacetylase (HDAC) inhibition and epigenetic modulation, which can restrict CRC cell proliferation and can induce apoptosis of CRC cells [28]. Butyrate plays an important role in host health through maintaining intestinal homeostasis, reinforcing the epithelial barrier, and inhibiting intestinal inflammation [29]. Thus, the depletion of butyrate-producing bacteria in the gut microbiota may increase the risk of CRC.

The above subset of studies recognises that there are variations between studies. However, there are a number of consistent patterns that may provide biomarkers for diagnostic purposes and may highlight potential therapeutic targets. Reducing abundances of Fusobacterium and increasing butyrate-producing genera within the gut microbiota may serve as a preventative strategy for CRC. While high abundances of specific genera are associated with CRC, specific bacterial species have also been implicated in the disease. 
Table 1. Examples of microbial patterns observed in colorectal cancer (CRC) patients.

\begin{tabular}{|c|c|c|c|c|c|c|c|c|}
\hline \multicolumn{2}{|c|}{ Sample Type } & $\begin{array}{c}\text { CRC } \\
\text { Samples }\end{array}$ & $\begin{array}{l}\text { Noncancer } \\
\text { Controls }\end{array}$ & Detection Method & $\begin{array}{l}\text { Probiotic/Antibiotic } \\
\text { Exclusion Criteria }\end{array}$ & Overrepresented Taxa & $\begin{array}{c}\text { Underrepresented } \\
\text { Taxa }\end{array}$ & Reference \\
\hline \multicolumn{2}{|c|}{ Tissue } & 65 & 65 & $\begin{array}{l}\text { 16S rRNA gene } \\
\text { (V4) } \\
\text { pyrosequencing }\end{array}$ & $\begin{array}{l}\text { No probiotic or } \\
\text { antibiotic exposure } \\
\text { within } 4 \text { weeks }\end{array}$ & $\begin{array}{c}\text { Fusobacterium, Streptococcus, } \\
\text { Peptostreptococcus, Porphyromonas, } \\
\text { and Selenomonas }\end{array}$ & Roseburia & {$[21]$} \\
\hline \multicolumn{2}{|c|}{ Tissue } & $31^{\mathrm{b}}$ & 20 & $\begin{array}{l}\text { 16S rRNA gene } \\
\text { (V3) } \\
\text { pyrosequencing }\end{array}$ & $\begin{array}{c}\text { No antibiotic } \\
\text { exposure within } \\
2 \text { months or probiotic } \\
\text { exposure within } \\
2 \text { weeks }\end{array}$ & $\begin{array}{c}\text { Firmicutes, Fusobacteria, } \\
\text { Lactococcus, and Fusobacterium }\end{array}$ & $\begin{array}{l}\text { Pseudomonas and } \\
\text { Escherichia/Shigella }\end{array}$ & {$[26]$} \\
\hline \multicolumn{2}{|c|}{ Tissue } & 65 & 65 & $\begin{array}{l}\text { 16S rRNA gene } \\
\quad \text { (V1-V3) } \\
\text { pyrosequencing }\end{array}$ & - & $\begin{array}{c}\text { Fusobacterium, Leptotrichia, and } \\
\text { Campylobacter }\end{array}$ & $\begin{array}{c}\text { Ruminococcus, } \\
\text { Parabacteroides, } \\
\text { Pseudoflavonifractor, } \\
\text { Ruminococcaceae, and } \\
\text { Holdemania }\end{array}$ & [25] \\
\hline \multicolumn{2}{|c|}{ Tissue and Mucosa } & 15 & 21 & $\begin{array}{l}\text { 16S rRNA gene } \\
\text { (V4) amplicon } \\
\text { sequencing }\end{array}$ & $\begin{array}{l}\text { Recent antibiotic } \\
\text { exposure or regular } \\
\text { use of probiotics }\end{array}$ & $\begin{array}{c}\text { Fusobacterium, } \\
\text { Peptostreptococcus, and } \\
\text { Selenomonas }\end{array}$ & $\begin{array}{l}\text { Roseburia and } \\
\text { Streptococcus }\end{array}$ & [22] \\
\hline Faecal & $9^{a}$ & 49 & $\begin{array}{r}\text { Next Gener } \\
\text { analysis \& } \\
\text { fragment le }\end{array}$ & $\begin{array}{l}\text { Sequence (NGS) } \\
\text { ninal restriction } \\
\text { h polymorphism } \\
\text { FLP) }\end{array}$ & $\begin{array}{l}\text { Current use of } \\
\text { antibiotics or regular } \\
\text { use of probiotics }\end{array}$ & $\begin{array}{c}\text { Actinomyces, Atopobium, } \\
\text { Fusobacterium, Haemophilus, } \\
\text { Bacteroides fragilis, Clostridium } \\
\text { nexile, Actinomyces odontolyticus } \\
\text { Heamophilus parainfluenzae, } \\
\text { Fusobacterium varium, Prevotella } \\
\text { stercorea, Veillonella dispar, and } \\
\text { Streptococcus gordonii }\end{array}$ & $\begin{array}{l}\text { Slackia and } \\
\text { Eubacterium } \\
\text { coprostanoligens }\end{array}$ & [24] \\
\hline Faecal & 46 & 56 & 16S rRNA ger & 3) pyrosequencing & $\begin{array}{l}\text { No antibiotic } \\
\text { exposure within } \\
3 \text { months }\end{array}$ & $\begin{array}{l}\text { Fusobacterium, Enterococcus, } \\
\text { Escherichia/Shigella, Klebsiella, } \\
\text { Streptococcus, and } \\
\text { Peptostreptococcus }\end{array}$ & Roseburia & [20] \\
\hline Faecal & 42 & 89 & $\begin{array}{r}16 \mathrm{~S} \text { rRI } \\
\mathrm{pyr}\end{array}$ & $\begin{array}{l}\text { gene (V3-V4) } \\
\text { quencing }\end{array}$ & - & Fusobacterium and Porphyromonas & $\begin{array}{l}\text { Clostridia and } \\
\text { Lachnospiraceae }\end{array}$ & [23] \\
\hline
\end{tabular}

${ }^{a}$ Fifty samples from patients with colon adenomas were also obtained. ${ }^{b}$ Samples were segregated into proximal and distal colon samples. 


\section{Specific Taxa Associated with CRC Development}

Metagenomic analysis have revealed a significant increase in the presence of commensal bacteria in the gut microbiome of CRC patients including strains of Escherichia coli, Bacteroides fragilis, and in particular F. nucleatum [30-32]. Studies have also shown that specific species increase the risk of developing CRC. For example, a 2018 retrospective analysis of 13,096 patients found that CRC risk was increased in patients with bacteremia caused by B. fragilis, Streptococcus gallolticus, F. nucleatum, Clostridium septicum, or Clostridium perfringens [33]. Specific bacterial species and several mechanisms have been implicated in the development of CRC, supporting a causal role. For instance, pathogenic bacteria may promote $\mathrm{CRC}$ through the production of genotoxins and virulence factors, the upregulation of inflammatory pathways, and the initiation of oxidative stress, which ultimately lead to genetic instability and epithelial cell proliferation [17]. Therefore, controlling particular components of the gut may serve to reduce the risk of CRC development. The most extensively studied CRC-associated bacteria are F. nucleatum, B. fragilis, and E. coli.

\subsection{F. nucleatum}

F. nucleatum is a Gram-negative and strict anaerobe that predominantly colonises the oral cavity and is implicated in periodontal diseases such as gingivitis and periodontitis [34]. It is also associated with many other diseases and adverse health outcomes including inflammatory bowel disease (IBD), appendicitis, preterm births, stillbirths, atherosclerosis, rheumatoid arthritis, and Alzheimer's [35-41]. Further to this, F. nucleatum has become an important human pathogen shown to be elevated in colonic tumours and localised with malignant colonic cells. An increased abundance of Fusobacterium species has been identified by transcriptomic and metagenomic profiling in colon cancer relative to healthy tissues [42-45]. Castellarin et al. [42] performed qPCR analysis on tumours of CRC patients and found an overrepresentation of F. nucleatum when compared to healthy tissue. High numbers of $F$. nucleatum have been found to correlate with the progression of colorectal carcinogenesis and molecular markers such as the CpG island methylator phenotype (CIMP) and colorectal tumours with evidence of microsatellite instability [46,47]. Park et al. [48] used $16 \mathrm{~S}$ rRNA sequencing to compare the gut microbiota of patients with precursors to CRC and patients diagnosed with CRC for the first time. Mucosal biopsy samples of patients with tubular adenomas (TA), sessile serrated adenomas/polyps (SSA/P), and CRC revealed no differences in relative abundance of Fusobacteria between TA (4.3\%) and SSA/P (1.9\%) groups. However, a significant difference in the relative abundance of Fusobacteria was observed in the CRC group (33.8\%) compared to TA and SSA/P groups. The Fusobacterium-CRC link was further strengthened, when Rezasoltani et al. [30] found an enrichment of F. nucleatum in adenomatous polyps compared with healthy matched controls. Ultimately, in 2018, a meta-analysis which included 122 studies associated high F. nucleatum numbers with the tumorigenesis pathway and the $\mathrm{CpG}$ island methylator phenotype [49]. Over time, evidence has continued to accumulate about the relationship between F. nucleatum and CRC going beyond a correlation, with the species now being viewed as a causative agent.

The virulent potential of the species and its ability to disrupt natural cell activities are largely attributable to FadA, a characterised virulence factor [50]. Rubinstein et al. [51] further characterised this phenotype as being a promoter of CRC via regulation of E-cadherin (adhesion molecule) and the transcription factor $\beta$-catenin, leading to increased expression of oncogenic and inflammatory genes. Furthermore, Ma et al. [52] outlined the role of F. nucleatum infection in promoting carcinogenesis by interacting with E-cadherin in a normal colon epithelial cell line (NCM460) while enhancing proliferation and activating NF- $\mathrm{kB}$ signalling. Furthermore, F. nucleatum increased inflammation and tumour multiplicity in an $\mathrm{Apc}^{\mathrm{Min} /+}$ mouse model of intestinal tumorigenesis [45]. F. nucleatum can promote inflammatory microenvironments by initiating the release of inflammatory cytokines [53]. Additionally, F. nucleatum can weaken host immune responses as antitumour immunity defences and natural killer (NK) cells are suppressed by F. nucleatum, ultimately inhibiting tumour killing [54]. Mima et al. [46] provided further evidence of immunosuppression when they correlated F. nucleatum and 
low-density CD3+ T-cells in colorectal carcinoma tissues. Further to this, F. nucleatum induced M2 polarization of antitumour macrophages, resulting in poor patient prognosis [55]. Causality was also demonstrated using RNA-seq technologies and functional assays to reveal that autophagy pathways were activated by F. nucleatum in CRC cells while apoptosis was inhibited. Interestingly, in the same study, F. nucleatum was shown to promote chemoresistance, which may explain why high abundances of $F$. nucleatum correlate with poor patient prognosis [56]. Thymocyte selection-associated high-mobility group box (TOX) is a highly conserved member of a family of DNA-binding proteins, which plays a role in cellular functions such as apoptosis, growth, DNA repair, and metastasis [57]. TOX expression was found to be reduced in F. nucleatum-positive malignant tissues of the colon compared with F. nucleatum negative tissues. The same study also supported recent findings associating F. nucleatum with low $\mathrm{T}$ cell densities, reporting low $\mathrm{CD}^{+} \mathrm{T}$ cell density in $\mathrm{F}$. nucleatum-positive malignancies compared to F. nucleatum-negative controls [58].

As noted, the aforementioned findings provide an insight into the role of F. nucleatum in the activation and progression of tumorigenesis through specific cancer pathways. By extension, reducing F. nucleatum colonisation in the gut and colon may reduce the risk of CRC development and, once CRC is established, may slow the progression of the disease. However, other species are also implicated in CRC.

\subsection{B. fragilis}

B. fragilis is a Gram-negative obligate anaerobe, ubiquitous in nature, and a predominant species in the gut microbiota [59]. While there are strains of $B$. fragilis that contribute to gut health and are being assessed as potential probiotics [60], a possible association between other B. fragilis and CRC has also been uncovered. For example, Purcell et al. [31] used qPCR analysis to show that elevated levels of Enterotoxigenic B. fragilis (ETBF) was associated with the early onset of colorectal carcinogenesis. B. fragilis is thought to promote colon carcinogenesis by stimulating cell proliferation and by inducing inflammation via the TH17-dependent pathway [61]. ETBF produces a 20-kDa metalloprotease virulence factor called B. fragilis toxin (BFT) [62]. The expression of BFT in mouse models induces persistent colitis, interferes with E-cadherin junctions, initiates $\beta$-catenin signalling, and activates IL-8 secretion in colonic epithelial cells (CECs) [63-65]. Sears et al. [66] reported that the NF-KB signalling pathway is initiated by BFT, leading to increased cell proliferation and initiation of inflammatory mediators resulting in mucosal inflammation and, ultimately, CRC. Recently, Chung et al. [67] used an intestinal tumorigenesis mouse model induced by B. fragilis in Apc ${ }^{\mathrm{Min}}$ mice to demonstrate the pro-carcinogenic effects of BFT and its ability to activate NFKB and Stat3, facilitating tumorigenesis. The presence of the BFT gene has been considered a biomarker for CRC [68] and, therefore, also highlights a therapeutic target.

\subsection{E. coli}

E. coli is a natural habitant of the gut microbiota and, in most cases, a commensal organism. Indeed, some strains are known for their probiotic properties [69], such as the E. coli Nissle 1917 strain. However, several $E$. coli strains are known to be encode numerous virulence factors and many studies demonstrate the genotoxic activities of some E. coli that disrupt natural cellular events and, ultimately, induce apoptosis [70-74]. E. coli harbouring polyketide synthase (pks) genotoxic islands secrete colibactin, a bacterial toxin, which may cause DNA damage and promote genomic alterations and instability [75]. Numerous studies have identified elevated levels of E. coli in CRC patients. For example, Bonnet et al. [32] reported a significant increase in mucosa-associated or internalized E. coli in CRC tumours compared to noncancerous controls. Furthermore, various levels of cyclomodulin-producing E. coli were found across different stages of colon cancer, with stages III and IV higher in abundance than stage I. Metagenomic analysis of patients diagnosed with advanced carcinoma also supports the role of $E$. coli in CRC [76]. Arthur et al. [77] provided mechanistic insight by demonstrating that pks+ E. coli NC101 promotes colorectal carcinogenesis in azoxymethane (AOM)-treated IL- $10^{-/-}$mice. Furthermore, a recent study identified pks+ E. coli and ETBF to be predominantly colonising biofilms in the colonic mucosa of 
patients diagnosed with familial adenomatous polyposis compared to healthy controls. Interestingly, the same study showed that mice harbouring both colibactin-secreting E. coli and ETBF showed increased tumorigenesis compared to mice harbouring E. coli or ETBF individually [78]. These findings suggest that genotoxin-producing $E$. coli and B. fragilis could be a synergistic driver of colon cancer.

\subsection{Other Bacteria}

While other bacteria have been associated with $\mathrm{CRC}$, the evidence for causation is limited and further studies are needed. For example, the human pathogen Salmonella enterica Serovar Enteritidis (S. enderitidis) has also been associated with CRC in a limited number of studies. S. enteritidis expresses a secretion protein, AvrA, which initiates Stat 3 and $\beta$-catenin signalling pathways, promoting cell proliferation and tumorigenesis [79]. An epidemiological study found increased risk of developing CRC after S. enteritidis infection relative to individuals who have not experienced infection by the pathogen [80]. Another example is Enterococcus faecalis, an emerging human pathogen of the GI tract [81], which was reported to be significantly more prevalent in patients with CRC compared to healthy control subjects [20,82]. However, its role in CRC is debated as some studies suggest protective properties; for example, heat-killed E. faecalis EC-12 was shown to decrease tumour size in the small intestine of a mouse model via downregulating $\beta$-catenin signalling [83]. This paradox likely reflects the considerable differences in the pathogenic potential of E. faecalis depending on the gene complement present.

In summary, the proposed mechanisms implicating bacterial pathogens in CRC are through bacterial toxin secretion, activation of inflammatory pathways, disruption of protection barriers, and interference of natural cellular events, resulting in chronic inflammation and genomic instability, which can lead to epithelial cellular proliferation and, ultimately, CRC; see Figure 1.

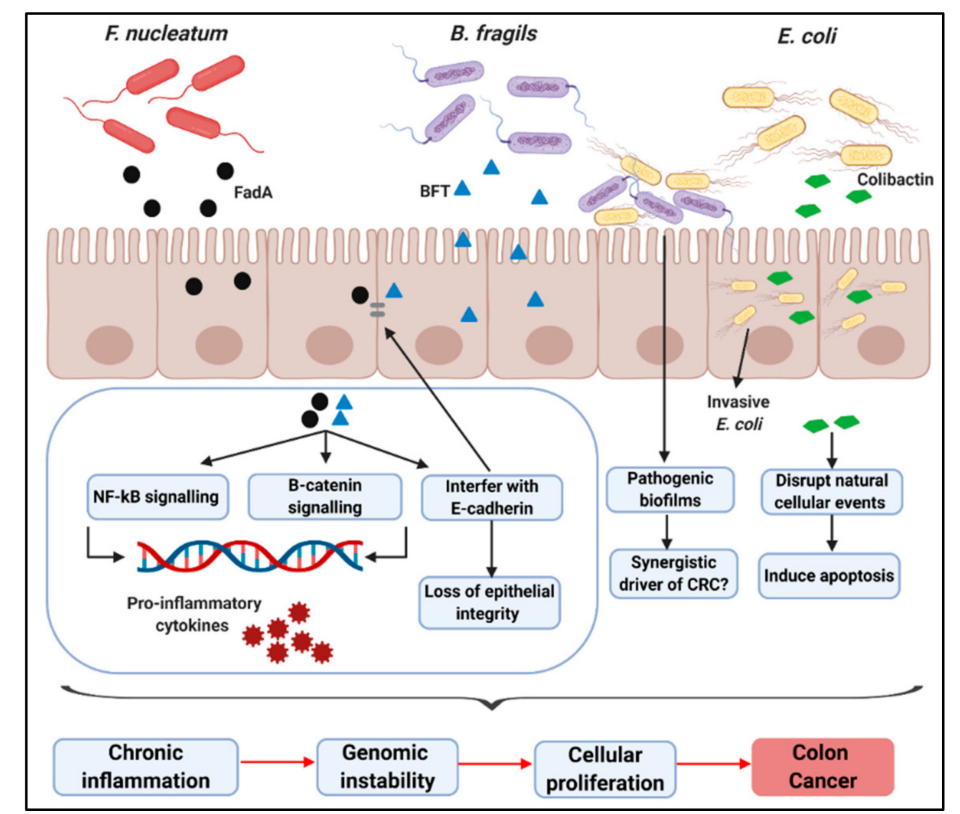

Figure 1. Overview of proposed mechanisms implicating principle CRC-associated bacterial pathogens in CRC development: Specific bacterial species may promote CRC through several mechanisms, such as the secretion of virulence factors by F. nucleatum (FadA) and B. fragilis (BFT), which activate NF-kB and $\beta$-catenin signaling pathways, leading to the development of pro-inflammatory cytokines which promotes pro-inflammatory microenvironments. Virulence factors may interfere with E-cadherin, a transmembrane protein essential for maintaining the epithelium cell layer, thus mediating the invasion of pathogenic bacteria. Cyclomodulin and genotoxin-producing E. coli (colibactin) may interfere with natural cellular events and may induce apoptosis. Biofilms predominantly colonized by genotoxinproducing E. coli and BFT-producing B. fragilis may be a synergistic driver of CRC. These events 
culminate in the development of chronic inflammation and genomic instability, which leads to epithelial cellular proliferation and, ultimately, CRC. This figure was created with BioRender.

\section{Potential Use of Biotherapeutic Bacteria to Target Colorectal Cancer-Associated Taxa}

The need for alternative therapies in this antibiotic resistance era is ever increasing. As the mechanisms through which specific bacterial species contribute to CRC are revealed, new strategies can be employed to reduce the growth of these species or, indeed, to eliminate them from the gut microbiota without harming beneficial bacteria in the process. Probiotics are now widely considered as a biotherapeutic and are defined as "live microorganisms that, when administered in adequate amounts, confer a health benefit on the host" [84]. Probiotic bacteria have potential as alternatives to antibiotics to control undesirable microbes through several mechanisms including antimicrobial (bacteriocin) production, competition for nutrients, and competitive exclusion of pathogens. Some antimicrobial-producing probiotics possess narrow spectrum activity against specific pathogenic bacteria and, thus, do not harm beneficial bacteria within the host microbiota. With regard to CRC, numerous clinical trials have shown the potential of probiotics as adjuvants, reducing the side effects associated with chemotherapy and surgeries in CRC-patients $[85,86]$. The delivery of live biotherapeutic cells for the treatment of GI diseases is well known and the immunomodulatory and anti-inflammatory properties of probiotics on colon cancer is well understood [87]; however, few studies exist that demonstrate the potential of probiotics to eradicate CRC-associated bacteria from the gut microbiome, consequently reducing the risk of disease development.

\section{Antimicrobial Activity of Biotherapeutic Strains against Fusobacterium nucleatum}

The correlation between F. nucleatum and CRC has been extensively demonstrated, and the potential mechanisms underlying the promotion and progression of the disease have been elucidated. There is little doubt that targeting this organism in the GI tract and that the potential development of microbiota-targeted therapies against $F$. nucleatum are promising research avenues. As F. nucleatum was first identified as a pathogen associated with periodontal disease, numerous studies demonstrate the potential use of oral strains to inhibit many dental pathogens in vitro, including strains of F. nucleatum [88-91]. For example, bio-yogurt was shown to have antimicrobial activity against a range of periodontal pathogens, including the F. nucleatum strains tested. Furthermore, Lactobacillus bulgaricus, Streptococcus thermophilus, Lactobacillus acidophilus, and Bifidobacterium spp. isolated from bio-yogurt demonstrated antimicrobial activity against oral pathogens by competition assays. Notably, Bifidobacterium and Streptococcus thermophilus demonstrated inhibitory activity against $F$. nucleatum [90]. Another study assessed the antibacterial activity of a number of strains against a range of oral pathogens by inoculating antimicrobial-producing lactic acid bacteria (LAB) with periodontal pathogens in 96-well plates and by evaluating growth inhibition by optical density (OD) measurements at $600 \mathrm{~nm}$ after $24 \mathrm{~h}$ of anaerobic incubation. Weissella cibaria CMU and two probiotic species isolated from commercial probiotic products, Lactobacillus salivarius and Lactobacillus reuteri, showed antimicrobial activity against F. nucleatum with more than $95 \%$ growth inhibition compared with other probiotic strains. Interestingly, W. cibaria CMU demonstrated the highest co-aggregation rate with F. nucleatum with $81.2 \%$ as compared with other cariogenic and periodontopathic bacteria [91]. Co-aggregation, a beneficial property of probiotics, is a process of attachment which influences multi-species biofilm formation and is considered a beneficial property of probiotic and other biotherapeutic strains, which may result in barrier formation that prevents colonisation of pathogenic bacteria [92]. The antimicrobial activity of probiotics against CRC-associated F. nucleatum has also been assessed in vitro. Guzel-Seydim et al. [93] reported the anti-F. nucleatum potential of kefir (produced from natural Kefir grains), commercial Kefir, and yogurt (produced from natural starter cultures) against $F$. nucleatum by disc diffusion assays. Natural kefir demonstrated the largest inhibitory effect against F. nucleatum. Kefir produced from kefir grains is considered a functional food and a source of potential probiotics. Some kefirs and associated strains have shown specific health benefits [94]. The microbial composition of kefir grains 
is complex; however, the genus Lactobacillus and specifically the species Lactobacillus kefiranofaciens can dominate [95]. Inhibition of F. nucleatum due to probiotic supplementation is also evident in vivo. For example, a randomised control trial, which included an oral microbiota analysis, revealed a reduction in several oral species including F. nucleatum subsp. vincentii after administration of probiotic strains Lactobacillus reuteri DSM 17,938 and PTA 5289 daily for 12 weeks [96]. Considering, the oral microbiota's influence on GI health and disease [97] and that bacteria associated with CRC are also found in the oral cavity, these findings suggest potential for oral lactobacilli to be active against CRC-associated F. nucleatum. While these observations are promising, whether the anti-F. nucleatum activity demonstrated by these strains will translate into the dynamic conditions of the GI tract is yet to be confirmed. Furthermore, the impact of these anti-F.nucleatum strains on the surrounding gut microbiota and host health must be evaluated.

\section{Probiotic Intervention Modulates the CRC-Associated Microbiome}

A reduction in cancer-associated taxa due to the administration of probiotics has also been revealed through human clinical trials [22,98]. A prospective controlled trial randomised 22 CRC patients into a group receiving a mixture of Bifidobacterium longum, Lactobacillus acidophilus, and Enterococcus faecalis at a concentration greater or equal to $1.0 \times 10^{7} \mathrm{CFU} / \mathrm{g}$ three times daily or into a control group receiving maltodextrin. Samples of mucosa were obtained from colonic tumour sites throughout surgery, and noncancerous mucosa samples were collected from various colonic areas. Amplification of the 16S rRNA V3 region and pyrosequencing revealed a significant reduction in Peptostreptococcus and Comamonas and, most notably, a 5-fold decrease in Fusobacterium numbers after administration of the probiotic mixture. Additionally, Proteobacteria and Enterococcus were more abundant in patients receiving probiotic treatment [98]. In another study, the colonic microbiota of CRC patients was assessed after probiotic intervention with subjects receiving oral tablets twice daily, containing a high concentration of Bifidobacterium lactis Bl-04 and Lactobacillus acidophilus NCFM, compared to healthy controls. Faecal samples were collected pre-intervention and, at the time of surgery and $16 \mathrm{~S}$ rRNA gene sequencing, were used to evaluate the microbial composition. Analysis revealed strong differences between the microbial composition of the mucosa and tumour tissue of patients receiving the probiotic compared to patients receiving no probiotics and to noncancerous controls. The taxa most associated with CRC, Fusobacterium, and Peptostreptococcus were less represented in the faecal samples of patients that received the probiotic. Additionally, butyrate-producing taxa Clostridiales spp, Faecalibacterium, Eubacterium, Roseburia, and Lachnopira were elevated in different sample types obtained from CRC patients receiving probiotic supplementation [22]. Although these studies were not species specific, it warrants further investigation into the use of microbial cocktails to control F. nucleatum and other CRC-associated bacteria. Ultimately, these studies show that strains exhibiting in vitro activity against $F$. nucleatum may exist and that there is the possibility that CRC-associated taxa may be manipulated through probiotic interventional therapy. However, targeting specific species associated with CRC while leaving beneficial taxa unharmed is desirable. Therefore, the influence of candidate biotherapeutic bacteria on the overall gut microbiome must be elucidated. Additionally, for the use of biotherapeutics, such as probiotics to target specific bacteria associated with CRC, they must be able to survive passage through the harsh conditions of the GI tract and to remain functionally unaltered. They must be evaluated for resistance to oral cavity enzymes, stomach $\mathrm{pH}$, bile salts, pancreatic juices, and intestinal mucus while demonstrate an ability to adhere to epithelial tissue. Further investigation of these and other strains with activity against CRC-associated taxa has considerable merit.

\section{Concluding Remarks}

Evidence associating bacterial species with CRC is rapidly increasing. Both metagenomic analysis and mechanistic studies continue to implicate bacterial pathogens in CRC development and disease progression. Thus, suppressing the growth of CRC-associated bacteria in the gut or colon may provide a strategy to reduce the overall risk of developing CRC. Further to this, eradicating the pathogens whilst 
leaving the surrounding gut microbiota unharmed is favourable. This may be achieved using narrow spectrum biotherapeutics, such as bacteriocin-producing probiotics. The above studies demonstrate the potential use of probiotic bacteria to target F. nucleatum, a bacterial pathogen associated with CRC. Although results obtained from in vitro studies do not necessarily translate into animal studies or human clinical trials, it offers potential for further research. The number of clinical trials evaluating the use of probiotics to manipulate specific bacterial species are limited, especially specific strains implicated in the CRC, but those that are available in the literature highlight the ability of probiotics to decrease abundances of Fusobacterium. Through the expression of antimicrobials and competitive exclusion, probiotics may serve as bio-controlling agents; see Figure 2. Their nontoxicity due to being natural residents of the gut microbiota further contributes to their safety and potential alternatives to antibiotics. Overall, the above studies demonstrate the use of probiotics to prevent the growth of F. nucleatum and to reduce CRC-associated taxa including Fusobacterium, which have been strongly associated with the development and progression of CRC and, therefore, showing promise in reducing the overall risk of CRC.Studies evaluating the use of probiotics to inhibit specific CRC-associated bacterial species have shown promising results for their use as a CRC-preventative strategy. Further research and clinical trials are needed to investigate the use of probiotics to target bacteria associated with CRC, positively impacting CRC outcomes.

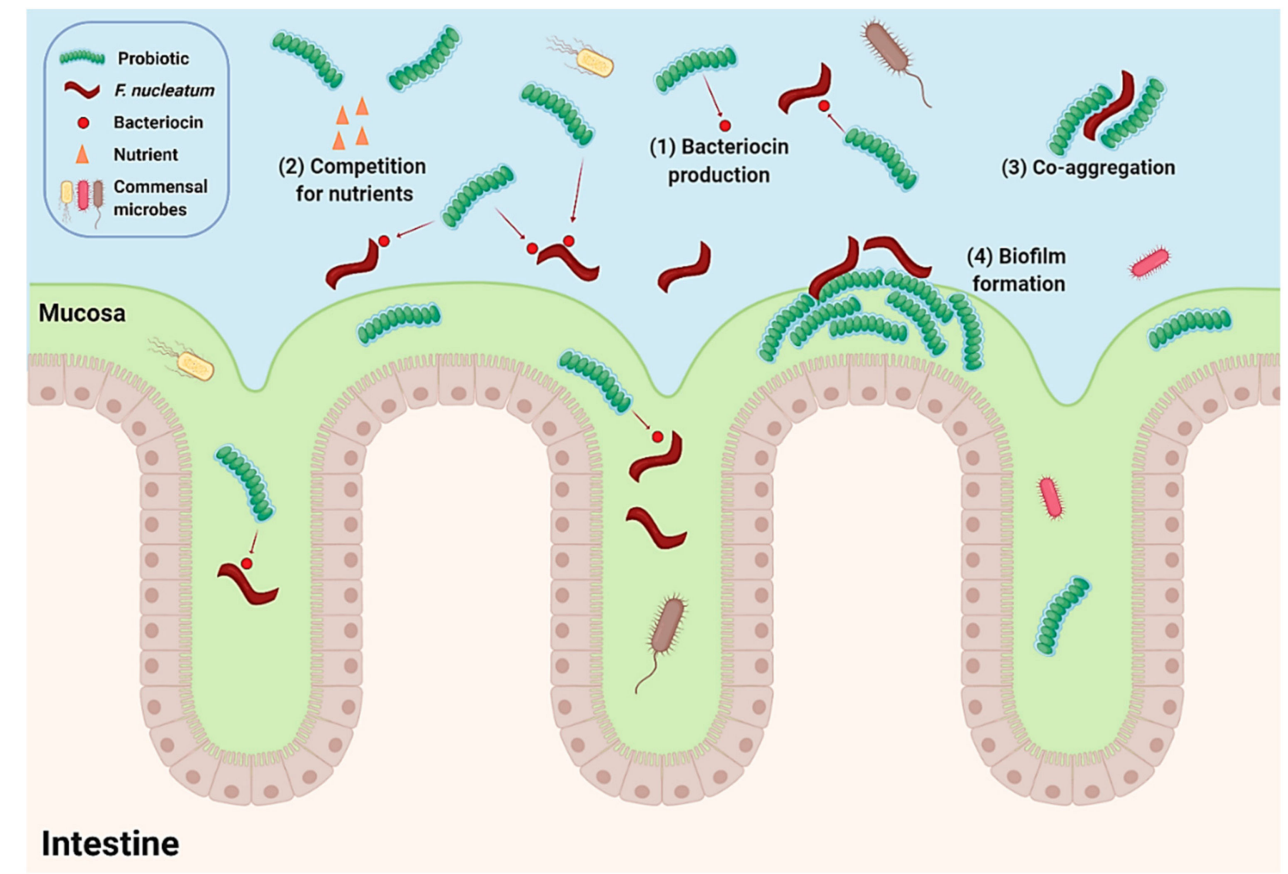

Figure 2. Proposed mechanism of action by which probiotic supplementation may decrease the risk of developing colon cancer by inhibiting F. nucleatum through (1) bacteriocin production, (2) competition for nutrients, (3) co-aggregation, and (4) competitive exclusion through biofilm formation. This figure was Created with BioRender.

Author Contributions: G.W.L. wrote the review and complied figures, tables and references. M.B. supervised, edited and approved the review. P.D.C. supervised, edited and approved the review. C.M.G. supervised, edited and approved the review. All authors have read and agreed to the published version of the manuscript.

Funding: This research received no external funding.

Acknowledgments: G.W.L. is in receipt of a Cork Institute of Technology RÍSAM Scholarship.

Conflicts of Interest: The authors declare no conflict of interest. 


\section{References}

1. What Is Colorectal Cancer? Available online: http://www.cancer.org/cancer/colon-rectal-cancer/about/whatis-colorectal-cancer.html (accessed on 20 January 2020).

2. Bray, F.; Ferlay, J.; Soerjomataram, I.; Siegel, R.L.; Torre, L.A.; Jemal, A. Global Cancer Statistics 2018: GLOBOCAN Estimates of Incidence and Mortality Worldwide for 36 Cancers in 185 Countries. CA. Cancer J. Clin. 2018, 68, 394-424. [CrossRef] [PubMed]

3. Grady, W.M.; Carethers, J.M. Genomic and Epigenetic Instability in Colorectal Cancer Pathogenesis. Gastroenterology 2008, 135, 1079-1099. [CrossRef] [PubMed]

4. Colussi, D.; Brandi, G.; Bazzoli, F.; Ricciardiello, L. Molecular Pathways Involved in Colorectal Cancer: Implications for Disease Behavior and Prevention. Int. J. Mol. Sci. 2013, 14, 16365-16385. [CrossRef] [PubMed]

5. Hong, S.N. Genetic and Epigenetic Alterations of Colorectal Cancer. Intest. Res. 2018, 16, 327-337. [CrossRef]

6. Larsson, S.C.; Wolk, A. Meat Consumption and Risk of Colorectal Cancer: A Meta-Analysis of Prospective Studies. Int. J. Cancer 2006, 119, 2657-2664. [CrossRef]

7. Riboli, E.; Norat, T. Epidemiologic Evidence of the Protective Effect of Fruit and Vegetables on Cancer Risk. Am. J. Clin. Nutr. 2003, 78, 559-569. [CrossRef]

8. Burnett-Hartman, A.N.; Newcomb, P.A.; Potter, J.D. Infectious Agents and Colorectal Cancer: A Review of Helicobacter Pylori, Streptococcus Bovis, JC Virus, and Human Papillomavirus. Cancer Epidemiol. Biomarkers Prev. 2008, 17, 2970-2979. [CrossRef]

9. Antonic, V.; Stojadinovic, A.; Kester, K.E.; Weina, P.J.; Brücher, B.L.; Protic, M.; Avital, I.; Izadjoo, M. Significance of Infectious Agents in Colorectal Cancer Development. J. Cancer 2013, 4, 227-240. [CrossRef]

10. Zou, S.; Fang, L.; Lee, M.-H. Dysbiosis of Gut Microbiota in Promoting the Development of Colorectal Cancer. Gastroenterol. Rep. 2018, 6, 1-12. [CrossRef]

11. Garrett, W.S. Cancer and the Microbiota. Science 2015, 348, 80-86. [CrossRef]

12. Kim, J.H. Chemotherapy for Colorectal Cancer in the Elderly. World J. Gastroenterol. 2015, 21, 5158-5166. [CrossRef]

13. Assed Bastos, D.; Freitas, D.; Coelho Ribeiro, S.; Hoff, P.M. Review: Combination Therapy in High-Risk Stage II or Stage III Colon Cancer: Current Practice and Future Prospects. Ther. Adv. Med. Oncol. 2010, 2, 261-272. [CrossRef] [PubMed]

14. Kocarnik, J.M.; Shiovitz, S.; Phipps, A.I. Molecular Phenotypes of Colorectal Cancer and Potential Clinical Applications. Gastroenterol. Rep. 2015, 3, 269-276. [CrossRef] [PubMed]

15. Gerber, D.E. Targeted Therapies: A New Generation of Cancer Treatments. Am. Fam. Physician 2008, 77, 311-319. [PubMed]

16. Stavrou, G.; Kotzampassi, K. Gut Microbiome, Surgical Complications and Probiotics. Ann. Gastroenterol. 2017, 30, 45-53. [CrossRef] [PubMed]

17. Gagnière, J.; Raisch, J.; Veziant, J.; Barnich, N.; Bonnet, R.; Buc, E.; Bringer, M.-A.; Pezet, D.; Bonnet, M. Gut Microbiota Imbalance and Colorectal Cancer. World J. Gastroenterol. 2016, 22, 501-518. [CrossRef] [PubMed]

18. Sun, J.; Kato, I. Gut Microbiota, Inflammation and Colorectal Cancer. Genes Dis. 2016, 3, 130-143. [CrossRef]

19. Jahani-Sherafat, S.; Alebouyeh, M.; Moghim, S.; Ahmadi Amoli, H.; Ghasemian-Safaei, H. Role of Gut Microbiota in the Pathogenesis of Colorectal Cancer; A Review Article. Gastroenterol. Hepatol. Bed Bench 2018, 11, 101-109.

20. Wang, T.; Cai, G.; Qiu, Y.; Fei, N.; Zhang, M.; Pang, X.; Jia, W.; Cai, S.; Zhao, L. Structural Segregation of Gut Microbiota between Colorectal Cancer Patients and Healthy Volunteers. ISME J. 2012, 6, 320-329. [CrossRef]

21. Gao, R.; Kong, C.; Huang, L.; Li, H.; Qu, X.; Liu, Z.; Lan, P.; Wang, J.; Qin, H. Mucosa-Associated Microbiota Signature in Colorectal Cancer. Eur. J. Clin. Microbiol. Infect. Dis. 2017, 36, 2073-2083. [CrossRef]

22. Hibberd, A.A.; Lyra, A.; Ouwehand, A.C.; Rolny, P.; Lindegren, H.; Cedgård, L.; Wettergren, Y. Intestinal Microbiota Is Altered in Patients with Colon Cancer and Modified by Probiotic Intervention. BMJ Open Gastroenterol. 2017, 4, e000145. [CrossRef] [PubMed]

23. Sinha, R.; Ahn, J.; Sampson, J.N.; Shi, J.; Yu, G.; Xiong, X.; Hayes, R.B.; Goedert, J.J. Fecal Microbiota, Fecal Metabolome, and Colorectal Cancer Interrelations. PLoS ONE 2016, 11, e0152126. [CrossRef] [PubMed] 
24. Kasai, C.; Sugimoto, K.; Moritani, I.; Tanaka, J.; Oya, Y.; Inoue, H.; Tameda, M.; Shiraki, K.; Ito, M.; Takei, Y.; et al. Comparison of Human Gut Microbiota in Control Subjects and Patients with Colorectal Carcinoma in Adenoma: Terminal Restriction Fragment Length Polymorphism and next-Generation Sequencing Analyses. Oncol. Rep. 2016, 35, 325-333. [CrossRef] [PubMed]

25. Warren, R.L.; Freeman, D.J.; Pleasance, S.; Watson, P.; Moore, R.A.; Cochrane, K.; Allen-Vercoe, E.; Holt, R.A. Co-Occurrence of Anaerobic Bacteria in Colorectal Carcinomas. Microbiome 2013, 1, 16. [CrossRef]

26. Gao, Z.; Guo, B.; Gao, R.; Zhu, Q.; Qin, H. Microbiota Disbiosis Is Associated with Colorectal Cancer. Front. Microbiol. 2015, 6, 20. [CrossRef]

27. Flemer, B.; Warren, R.D.; Barrett, M.P.; Cisek, K.; Das, A.; Jeffery, I.B.; Hurley, E.; O’Riordain, M.; Shanahan, F.; O'Toole, P.W. The Oral Microbiota in Colorectal Cancer Is Distinctive and Predictive. Gut 2018, 67, 1454-1463. [CrossRef]

28. Wu, X.; Wu, Y.; He, L.; Wu, L.; Wang, X.; Liu, Z. Effects of the Intestinal Microbial Metabolite Butyrate on the Development of Colorectal Cancer. J. Cancer 2018, 9, 2510-2517. [CrossRef]

29. Canani, R.B.; Costanzo, M.D.; Leone, L.; Pedeta, M.; Meli, R.; Calignano, A. Potential beneficial effects of butyrate in intestinal and extraintestinal diseases. World J. Gastroenterol. 2011, 17, 1519-1528. [CrossRef]

30. Rezasoltani, S.; Aghdaei, H.A.; Dabiri, H.; Sepahi, A.A.; Modarressi, M.H.; Mojarad, N. The Association between Fecal Microbiota and Different Types of Colorectal Polyp as Precursors of Colorectal Cancer. Microb. Pathog. 2018, 124, 244-249. [CrossRef]

31. Purcell, R.V.; Pearson, J.; Aitchison, A.; Dixon, L.; Frizelle, F.A.; Keenan, J.I. Colonization with Enterotoxigenic Bacteroides Fragilis Is Associated with Early-Stage Colorectal Neoplasia. PLoS ONE 2017, 12, e0171602. [CrossRef]

32. Bonnet, M.; Buc, E.; Sauvanet, P.; Darcha, C.; Dubois, D.; Pereira, B.; Dechelotte, P.; Bonnet, R.; Pezet, D.; Darfeuille-Michaud, A. Colonization of the Human Gut by E. Coli and Colorectal Cancer Risk. Clin. Cancer Res. 2014, 20, 859-867. [CrossRef] [PubMed]

33. Kwong, T.N.Y.; Wang, X.; Nakatsu, G.; Chow, T.C.; Tipoe, T.; Dai, R.Z.W.; Tsoi, K.K.K.; Wong, M.C.S.; Tse, G.; Chan, M.T.V.; et al. Association Between Bacteremia From Specific Microbes and Subsequent Diagnosis of Colorectal Cancer. Gastroenterology 2018, 155, 383-390. [CrossRef] [PubMed]

34. Liu, P.; Liu, Y.; Wang, J.; Guo, Y.; Zhang, Y.; Xiao, S. Detection of Fusobacterium Nucleatum and FadA Adhesin Gene in Patients with Orthodontic Gingivitis and Non-Orthodontic Periodontal Inflammation. PLoS ONE 2014, 9, e85280. [CrossRef] [PubMed]

35. Lee, Y.; Eun, C.S.; Lee, A.R.; Park, C.H.; Han, D.S. Fusobacterium Isolates Recovered From Colonic Biopsies of Inflammatory Bowel Disease Patients in Korea. Ann. Lab. Med. 2016, 36, 387-389. [CrossRef]

36. Swidsinski, A.; Dorffel, Y.; Loening-Baucke, V.; Theissig, F.; Ruckert, J.C.; Ismail, M.; Rau, W.A.; Gaschler, D.; Weizenegger, M.; Kuhn, S.; et al. Acute Appendicitis Is Characterised by Local Invasion with Fusobacterium Nucleatum/Necrophorum. Gut 2011, 60, 34-40. [CrossRef]

37. Vander Haar, E.L.; So, J.; Gyamfi-Bannerman, C.; Han, Y.W. Fusobacterium Nucleatum and Adverse Pregnancy Outcomes: Epidemiological and Mechanistic Evidence. Anaerobe 2018, 50, 55-59. [CrossRef]

38. Chhibber-Goel, J.; Singhal, V.; Bhowmik, D.; Vivek, R.; Parakh, N.; Bhargava, B.; Sharma, A. Linkages between Oral Commensal Bacteria and Atherosclerotic Plaques in Coronary Artery Disease Patients. NPJ Biofilms Microbiomes 2016, 2, 7. [CrossRef]

39. Koziel, J.; Mydel, P.; Potempa, J. The Link Between Periodontal Disease and Rheumatoid Arthritis: An Updated Review. Curr. Rheumatol. Rep. 2014, 16, 408. [CrossRef]

40. Sparks Stein, P.; Steffen, M.J.; Smith, C.; Jicha, G.; Ebersole, J.L.; Abner, E.; Dawson, D. Serum Antibodies to Periodontal Pathogens Are a Risk Factor for Alzheimer's Disease. Alzheimer's Dement. 2012, 8, 196-203. [CrossRef]

41. Guinane, C.M.; Tadrous, A.; Fouhy, F.; Ryan, C.A.; Dempsey, E.M.; Murphy, B.; Andrews, E.; Cotter, P.D.; Stanton, C.; Ross, P.R. Microbial composition of human appendices from patients following appendectomy. mBio 2013, 4, e00366-12. [CrossRef]

42. Castellarin, M.; Warren, R.L.; Freeman, J.D.; Dreolini, L.; Krzywinski, M.; Strauss, J.; Barnes, R.; Watson, P.; Allen-Vercoe, E.; Moore, R.A.; et al. Fusobacterium Nucleatum Infection Is Prevalent in Human Colorectal Carcinoma. Genome Res. 2012, 22, 299-306. [CrossRef] [PubMed]

43. Chen, W.; Liu, F.; Ling, Z.; Tong, X.; Xiang, C. Human Intestinal Lumen and Mucosa-Associated Microbiota in Patients with Colorectal Cancer. PLoS ONE 2012, 7, e39743. [CrossRef] [PubMed] 
44. Flanagan, L.; Schmid, J.; Ebert, M.; Soucek, P.; Kunicka, T.; Liska, V.; Bruha, J.; Neary, P.; Dezeeuw, N.; Tommasino, M.; et al. Fusobacterium Nucleatum Associates with Stages of Colorectal Neoplasia Development, Colorectal Cancer and Disease Outcome. Eur. J. Clin. Microbiol. Infect. Dis. 2014, 33, 1381-1390. [CrossRef] [PubMed]

45. Kostic, A.D.; Chun, E.; Robertson, L.; Glickman, J.N.; Gallini, C.A.; Michaud, M.; Clancy, T.E.; Chung, D.C.; Lochhead, P.; Hold, G.L.; et al. Fusobacterium Nucleatum Potentiates Intestinal Tumorigenesis and Modulates the Tumor-Immune Microenvironment. Cell Host Microbe 2013, 14, 207-215. [CrossRef]

46. Mima, K.; Sukawa, Y.; Nishihara, R.; Qian, Z.R.; Yamauchi, M.; Inamura, K.; Kim, S.A.; Masuda, A.; Nowak, J.A.; Nosho, K.; et al. Fusobacterium Nucleatum and T Cells in Colorectal Carcinoma. JAMA Oncol. 2015, 1, 653. [CrossRef]

47. Tahara, T.; Yamamoto, E.; Suzuki, H.; Maruyama, R.; Chung, W.; Garriga, J.; Jelinek, J.; Yamano, H.-O.; Sugai, T.; An, B.; et al. Fusobacterium in Colonic Flora and Molecular Features of Colorectal Carcinoma. Cancer Res. 2014, 74, 1311-1318. [CrossRef]

48. Park, C.H.; Han, D.S.; Oh, Y.-H.; Lee, A.-R.; Lee, Y.-R.; Eun, C.S. Role of Fusobacteria in the Serrated Pathway of Colorectal Carcinogenesis. Sci. Rep. 2016, 6, 25271. [CrossRef]

49. Advani, S.M.; Advani, P.; DeSantis, S.M.; Brown, D.; VonVille, H.M.; Lam, M.; Loree, J.M.; Mehrvarz Sarshekeh, A.; Bressler, J.; Lopez, D.S.; et al. Clinical, Pathological, and Molecular Characteristics of CpG Island Methylator Phenotype in Colorectal Cancer: A Systematic Review and Meta-Analysis. Transl. Oncol. 2018, 11, 1188-1201. [CrossRef]

50. Xu, M.; Yamada, M.; Li, M.; Liu, H.; Chen, S.G.; Han, Y.W. FadA from Fusobacterium Nucleatum Utilizes Both Secreted and Nonsecreted Forms for Functional Oligomerization for Attachment and Invasion of Host Cells. J. Biol. Chem. 2007, 282, 25000-25009. [CrossRef]

51. Rubinstein, M.R.; Wang, X.; Liu, W.; Hao, Y.; Cai, G.; Han, Y.W. Fusobacterium Nucleatum Promotes Colorectal Carcinogenesis by Modulating E-Cadherin/ $\beta$-Catenin Signaling via Its FadA Adhesin. Cell Host Microbe 2013, 14, 195-206. [CrossRef]

52. Ma, C.-T.; Luo, H.-S.; Gao, F.; Tang, Q.-C.; Chen, W. Fusobacterium Nucleatum Promotes the Progression of Colorectal Cancer by Interacting with E-Cadherin. Oncol. Lett. 2018, 16, 2606-2612. [CrossRef] [PubMed]

53. Quah, S.Y.; Bergenholtz, G.; Tan, K.S. Fusobacterium Nucleatum Induces Cytokine Production through Toll-like-Receptor-Independent Mechanism. Int. Endod. J. 2014, 47, 550-559. [CrossRef] [PubMed]

54. Gur, C.; Ibrahim, Y.; Isaacson, B.; Yamin, R.; Abed, J.; Gamliel, M.; Enk, J.; Bar-On, Y.; Stanietsky-Kaynan, N.; Coppenhagen-Glazer, S.; et al. Binding of the Fap2 Protein of Fusobacterium Nucleatum to Human Inhibitory Receptor TIGIT Protects Tumors from Immune Cell Attack. Immunity 2015, 42, 344-355. [CrossRef] [PubMed]

55. Chen, T.; Li, Q.; Wu, J.; Wu, Y.; Peng, W.; Li, H.; Wang, J.; Tang, X.; Peng, Y.; Fu, X. Fusobacterium Nucleatum Promotes M2 Polarization of Macrophages in the Microenvironment of Colorectal Tumours via a TLR4-Dependent Mechanism. Cancer Immunol. Immunother. 2018, 67, 1635-1646. [CrossRef] [PubMed]

56. Yu, T.C.; Guo, F.; Yu, Y.; Sun, T.; Ma, D.; Han, J.; Qian, Y.; Kryczek, I.; Sun, D.; Nagarsheth, N.; et al. Fusobacterium Nucleatum Promotes Chemoresistance to Colorectal Cancer by Modulating Autophagy. Cell 2017, 70, 548-563. [CrossRef] [PubMed]

57. Yu, X.; Li, Z. TOX Gene: A Novel Target for Human Cancer Gene Therapy. Am. J. Cancer Res. 2015, 5, 3516-3524.

58. Chen, T.; Li, Q.; Zhang, X.; Wu, Y.; Wu, J. Original Contribution TOX Expression Decreases with Progression of Colorectal Cancers and Is Associated with CD4 T-Cell Density and Fusobacterium Nucleatum Infection. Hum. Pathol. 2018, 79, 93-101. [CrossRef]

59. Könönen, E.; Jousimies-Somer, H.; Asikainen, S. Relationship between Oral Gram-Negative Anaerobic Bacteria in Saliva of the Mother and the Colonization of Her Edentulous Infant. Oral Microbiol. Immunol. 1992, 7, 273-276. [CrossRef]

60. Wang, Y.; Deng, H.; Li, Z.; Tan, Y.; Han, Y.; Wang, X.; Du, Z.; Liu, Y.; Yang, R.; Bai, Y.; et al. Safety Evaluation of a Novel Strain of Bacteroides Fragilis. Front. Microbiol. 2017, 8, 435. [CrossRef]

61. Culpepper, B.S.T.; Mai, V. Evidence for Contributions of Gut Microbiota to Colorectal Carcinogenesis. Curr. Nutr. Rep. 2013, 2, 10. [CrossRef]

62. Kling, J.J.; Wright, R.L.; Moncrief, J.S.; Wilkins, T.D. Cloning and Characterization of the Gene for the Metalloprotease Enterotoxin of Bacteroides Fragilis. FEMS Microbiol. Lett. 1997, 146, 279-284. [CrossRef] [PubMed] 
63. Wu, S.; Lim, K.C.; Huang, J.; Saidi, R.F.; Sears, C.L. Bacteroides Fragilis Enterotoxin Cleaves the Zonula Adherens Protein, E-Cadherin. Proc. Natl. Acad. Sci. USA 1998, 95, 14979-14984. [CrossRef] [PubMed]

64. Hwang, S.; Gwon, S.-Y.; Kim, M.S.; Lee, S.; Rhee, K.-J. Bacteroides Fragilis Toxin Induces IL-8 Secretion in HT29/C1 Cells through Disruption of E-Cadherin Junctions. Immune Netw. 2013, 13, 213-217. [CrossRef] [PubMed]

65. Sanfilippo, L.; Li, C.K.; Seth, R.; Balwin, T.J.; Menozzi, M.G.; Mahida, Y.R. Bacteroides Fragilis Enterotoxin Induces the Expression of IL-8 and Transforming Growth Factor-Beta (TGF-Beta) by Human Colonic Epithelial Cells. Clin. Exp. Immunol. 2000, 119, 456-463. [CrossRef]

66. Sears, C.L.; Geis, A.L.; Housseau, F. Bacteroides Fragilis Subverts Mucosal Biology: From Symbiont to Colon Carcinogenesis. J. Clin. Invest. 2014, 124, 4166-4172. [CrossRef]

67. Chung, L.; Thiele Orberg, E.; Geis, A.L.; Chan, J.L.; Fu, K.; DeStefano Shields, C.E.; Dejea, C.M.; Fathi, P.; Chen, J.; Finard, B.B.; et al. Bacteroides Fragilis Toxin Coordinates a Pro-Carcinogenic Inflammatory Cascade via Targeting of Colonic Epithelial Cells. Cell Host Microbe 2018, 23, 203-214. [CrossRef]

68. Boleij, A.; Hechenbleikner, E.M.; Goodwin, A.C.; Badani, R.; Stein, E.M.; Lazarev, M.G.; Ellis, B.; Carroll, K.C.; Albesiano, E.; Wick, E.C.; et al. The Bacteroides Fragilis Toxin Gene Is Prevalent in the Colon Mucosa of Colorectal Cancer Patients. Clin. Infect. Dis. 2015, 60, 208-215. [CrossRef]

69. Wassenaar, T.M. Insights from 100 Years of Research with Probiotic E. Coli. Eur. J. Microbiol. Immunol. (Bp) 2016, 6, 147. [CrossRef]

70. Falzano, L.; Filippini, P.; Travaglione, S.; Miraglia, A.G.; Fabbri, A.; Fiorentini, C. Escherichia Coli Cytotoxic Necrotizing Factor 1 Blocks Cell Cycle G2/M Transition in Uroepithelial Cells. Infect. Immun. 2006, 74, 3765-3772. [CrossRef]

71. Malorni, W.; Fiorentini, C. Is the Rac GTPase-Activating Toxin CNF1 a Smart Hijacker of Host Cell Fate? FASEB J. 2006, 20, 606-609. [CrossRef]

72. Jubelin, G.; Chavez, C.V.; Taieb, F.; Banfield, M.J.; Samba-Louaka, A.; Nobe, R.; Nougayrède, J.-P.; Zumbihl, R.; Givaudan, A.; Escoubas, J.-M.; et al. Cycle Inhibiting Factors (CIFs) Are a Growing Family of Functional Cyclomodulins Present in Invertebrate and Mammal Bacterial Pathogens. PLoS ONE 2009, 4, e4855. [CrossRef] [PubMed]

73. Nougayrede, J.-P.; Homburg, S.; Taieb, F.; Boury, M.; Brzuszkiewicz, E.; Gottschalk, G.; Buchrieser, C.; Hacker, J.; Dobrindt, U.; Oswald, E. Escherichia Coli Induces DNA Double-Strand Breaks in Eukaryotic Cells. Science 2006, 313, 848-851. [CrossRef] [PubMed]

74. Cuevas-Ramos, G.; Petit, C.R.; Marcq, I.; Boury, M.; Oswald, E.; Nougayrède, J.-P. Escherichia Coli Induces DNA Damage in Vivo and Triggers Genomic Instability in Mammalian Cells. Proc. Natl. Acad. Sci. USA 2010, 107, 11537-11542. [CrossRef] [PubMed]

75. Faïs, T.; Delmas, J.; Barnich, N.; Bonnet, R.; Dalmasso, G. Colibactin: More Than a New Bacterial Toxin. Toxins 2018, 10. [CrossRef] [PubMed]

76. Feng, Q.; Liang, S.; Jia, H.; Stadlmayr, A.; Tang, L.; Lan, Z.; Zhang, D.; Xia, H.; Xu, X.; Jie, Z.; et al. Gut Microbiome Development along the Colorectal Adenoma-carcinoma Sequence. Nat. Commun. 2015, 6, 6528. [CrossRef] [PubMed]

77. Arthur, J.C.; Perez-Chanona, E.; Muhlbauer, M.; Tomkovich, S.; Uronis, J.M.; Fan, T.-J.; Campbell, B.J.; Abujamel, T.; Dogan, B.; Rogers, A.B.; et al. Intestinal Inflammation Targets Cancer-Inducing Activity of the Microbiota. Science 2012, 338, 120-123. [CrossRef]

78. Dejea, C.M.; Fathi, P.; Craig, J.M.; Boleij, A.; Taddese, R.; Geis, A.L.; Wu, X.; DeStefano Shields, C.E.; Hechenbleikner, E.M.; Huso, D.L.; et al. Patients with Familial Adenomatous Polyposis Harbor Colonic Biofilms Containing Tumorigenic Bacteria. Science 2018, 359, 592-597. [CrossRef]

79. Garcia, E.F.; Luciano, W.A.; Xavier, D.E.; da Costa, W.C.A.; de Sousa Oliveira, K.; Franco, O.L.; de Morais Júnior, M.A.; Lucena, B.T.L.; Picão, R.C.; Magnani, M.; et al. Identification of Lactic Acid Bacteria in Fruit Pulp Processing Byproducts and Potential Probiotic Properties of Selected Lactobacillus Strains. Front. Microbiol. 2016, 7, 1371. [CrossRef]

80. Mughini-Gras, L.; Schaapveld, M.; Kramers, J.; Mooij, S.; Neefjes-Borst, E.A.; Pelt, W.V.; Neefjes, J. Increased Colon Cancer Risk after Severe Salmonella Infection. PLoS ONE 2018, 13, e0189721. [CrossRef]

81. Pillar, C.M.; Gilmore, M.S. Enterococcal Virulence-Pathogenicity Island of E. Faecalis. Front. Biosci. 2004, 9, 2335-2346. [CrossRef] 
82. Balamurugan, R.; Rajendiran, E.; George, S.; Samuel, G.V.; Ramakrishna, B.S. Real-Time Polymerase Chain Reaction Quantification of Specific Butyrate-Producing Bacteria, Desulfovibrio and Enterococcus Faecalis in the Feces of Patients with Colorectal Cancer. J. Gastroenterol. Hepatol. 2008, 23, 1298-1303. [CrossRef] [PubMed]

83. Miyamoto, S.; Komiya, M.; Fujii, G.; Hamoya, T.; Nakanishi, R.; Fujimoto, K.; Tamura, S.; Kurokawa, Y.; Takahashi, M.; Ijichi, T.; et al. Preventive Effects of Heat-Killed Enterococcus Faecalis Strain EC-12 on Mouse Intestinal Tumor Development. Int. J. Mol. Sci. 2017, 18, 826. [CrossRef] [PubMed]

84. Hill, C.; Guarner, F.; Reid, G.; Gibson, G.R.; Merenstein, D.J.; Pot, B.; Morelli, L.; Canani, R.B.; Flint, H.J.; Salminen, S.; et al. The International Scientific Association for Probiotics and Prebiotics Consensus Statement on the Scope and Appropriate Use of the Term Probiotic. Nat. Rev. Gastroenterol. Hepatol. 2014, 11, 506-514. [CrossRef] [PubMed]

85. Aisu, N.; Tanimura, S.; Yamashita, Y.; Yamashita, K.; Maki, K.; Yoshida, Y.; Sasaki, T.; Takeno, S.; Hoshino, S. Impact of Perioperative Probiotic Treatment for Surgical Site Infections in Patients with Colorectal Cancer. Exp. Ther. Med. 2015, 10, 966-972. [CrossRef]

86. Yang, Y.; Xia, Y.; Chen, H.; Hong, L.; Feng, J.; Yang, J.; Yang, Z.; Shi, C.; Wu, W.; Gao, R.; et al. The Effect of Perioperative Probiotics Treatment for Colorectal Cancer: Short-Term Outcomes of a Randomized Controlled Trial. Oncotarget 2016, 7, 8432-8440. [CrossRef]

87. Prakash, S.; Urbanska, A.M. Colon-targeted delivery of live bacterial cell biotherapeutics including microencapsulated live bacterial cells. Biologics: Targets and Therapy 2008, 2, 355-378. [CrossRef]

88. Samot, J.; Badet, C. Clinical Microbiology Antibacterial Activity of Probiotic Candidates for Oral Health. Anaerobe 2013, 19, 34-38. [CrossRef]

89. Samot, J.; Belkhelfa, H.; Haddioui, L.; Badet, C. Probiotic Properties of Lactobacilli That Could Be Used Against Periodontitis. Probiotics Heal. 2017, 5, 3. [CrossRef]

90. Zhu, Y.; Xiao, L.; Shen, D.; Hao, Y. Competition between Yogurt Probiotics and Periodontal Pathogens in Vitro. Acta Odontol. Scand. 2010, 68, 261-268. [CrossRef]

91. Jang, H.J.; Kang, M.S.; Yi, S.H.; Hong, J.Y.; Hong, S.P. Comparative Study on the Characteristics of Weissella Cibaria CMU and Probiotic Strains for Oral Care. Molecules 2016, 21. [CrossRef]

92. Schellenberg, J.; Smoragiewicz, W.; Karska-Wysocki, B. A Rapid Method Combining Immunofluorescence and Flow Cytometry for Improved Understanding of Competitive Interactions between Lactic Acid Bacteria (LAB) and Methicillin-Resistant S. Aureus (MRSA) in Mixed Culture. J. Microbiol. Methods 2005, 65, 1-9. [CrossRef] [PubMed]

93. Güzel-Seydim, Z.B.; Ece Cagdas, M.D.; Seydim, A.C. Effect of Kefir on Fusobacterium Nucleatum Potentially Causing Intestinal Cancer. Funct. Foods Heal. Dis. 2016, 6, 469. [CrossRef]

94. Bourrie, B.C.T.; Willing, B.P.; Cotter, P.D. The Microbiota and Health Promoting Characteristics of the Fermented Beverage Kefir. Front. Microbiol. 2016, 7, 647. [CrossRef] [PubMed]

95. Walsh, A.M.; Crispie, F.; Kilcawley, K.; O'Sullivan, O.; O'Sullivan, M.G.; Claesson, M.J.; Cotter, P.D. Microbial Succession and Flavor Production in the Fermented Dairy Beverage Kefir. mSystems 2016, 1, e00052-16. [CrossRef]

96. Romani Vestman, N.; Chen, T.; Lif Holgerson, P.; Öhman, C.; Johansson, I. Oral Microbiota Shift after 12-Week Supplementation with Lactobacillus Reuteri DSM 17938 and PTA 5289; A Randomized Control Trial. PLoS ONE 2015, 10, e0125812. [CrossRef] [PubMed]

97. Olsen, I.; Yamazaki, K. Can Oral Bacteria Affect the Microbiome of the Gut? J. Oral Microbiol. 2019, 11, 1586422. [CrossRef] [PubMed]

98. Gao, Z.; Guo, B.; Gao, R.; Zhu, Q.; Wu, W.; Qin, H. Probiotics Modify Human Intestinal Mucosa-Associated Microbiota in Patients with Colorectal Cancer. Mol. Med. Rep. 2015, 12, 6119-6127. [CrossRef]

(C) 2020 by the authors. Licensee MDPI, Basel, Switzerland. This article is an open access article distributed under the terms and conditions of the Creative Commons Attribution (CC BY) license (http://creativecommons.org/licenses/by/4.0/). 